See discussions, stats, and author profiles for this publication at: https://www.researchgate.net/publication/327844362

\title{
Has the Gender Gap in Voter Turnout Really Disappeared?
}

Article in West European Politics · September 2018

DOI: $10.1080 / 01402382.2018 .1504486$

CITATIONS

0

3 authors:

Cilip Kostelka

(2) University of Essex

11 PUBliCATIONS 75 CITATIONS

SEE PROFILE

Elisabeth Gidengil

13. McGill University

118 PUBLICATIONS 2,321 CITATIONS

SEE PROFILE

Some of the authors of this publication are also working on these related projects:

Health and Political Engagement View project

Political Participation View project
READS

323

André Blais

Université de Montréal

389 PUBLICATIONS 8,252 CITATIONS

SEE PROFILE 
Title: Has the Gender Gap in Voter Turnout Really Disappeared?

Filip Kostelka, ${ }^{1}$ André Blais, and Elisabeth Gidengil

\section{This paper can be referred to as follows:}

Kostelka, Filip, André Blais, and Elisabeth Gidengil, forthcoming,"Has the Gender Gap in Voter Turnout Really Disappeared?", West European Politics, doi: 10.1080/01402382.2018.1504486.

\section{Acknowledgment}

We thank Damien Bol, the members of the Research Chair in Electoral Studies at the University of Montreal, the participants in the 2016 ECPR general conference in Prague, and this journal's reviewers and editors for helpful comments on the previous drafts of this manuscript.

\footnotetext{
${ }^{1}$ filip.kostelka@sciencespo.fr
} 


\begin{abstract}
:
According to conventional wisdom, the traditional gender gap in voting has disappeared or even reversed in most established democracies. Drawing on the existing literature on sex differences in political engagement and on pioneering voter turnout theories, this article questions the conventional assumption and hypothesises that women still participate at lower rates in less important elections. It systematically tests this hypothesis by exploring the impact of sex on voter turnout in different electoral arenas. The empirical analyses of two crossnational datasets (Making Electoral Democracy Work and the European Election Study) demonstrate that although there is generally no gender gap in first-order elections, women tend to vote less than men in second-order contests. This reflects women's weaker interest in politics and their lower levels of knowledge about politics in second-order electoral arenas.
\end{abstract}


The question of sex differences in electoral participation has a long pedigree in political science (e.g. Gosnell, 1930; Tingsten 1963; Verba et al. 1978). Writing in 1955, Duverger (p. 14) highlighted "a problem of women non-voters." Lower voting rates on the part of women were typically attributed to social norms, structural and situational factors, or women's late enfranchisement (e.g. Norris 2002; Franklin 2004; Mayer 2010: 116). The latter explanation is corroborated by the fact that in established democracies the gender gap in turnout gradually shrank as new cohorts of women entered the electorate. Thus, by the turn of the $21^{\text {st }}$ century, Verba et al. (1997: 3) were referring to "the well-known equivalence in voter turnout" in U.S. elections. More broadly, researchers have observed that, "traditional gender differences in voting participation diminished in the 1980s and 1990s, or even reversed, in many advanced industrialized countries" (Norris 2002: 96).

However, these optimistic assessments are mostly based on national elections. In today's era of multilevel governance, it is essential to examine the relationship between sex and electoral participation at different levels of government. Drawing on pioneering works in political science, recent research on sex differences in political engagement, and large-scale survey data from national, subnational and supranational elections, we challenge the widespread belief that established democracies have achieved full sex equality in voter turnout.

We start by formulating a theoretically grounded hypothesis regarding sex differences in voter turnout in second-order elections. In line with earlier research, we argue that voting in these elections is more strongly driven by political interest and political knowledge. When asked in surveys, women in most established democracies express lower levels of political interest and give fewer correct answers to political knowledge questions than men (Inglehart 1981; Verba et al. 1997; Burns et al. 2001; Gidengil et al. 2004; Stolle and Gidengil 2010; Kittilson and Schwindt-Bayer 2010, Fraile 2014, Dassonneville and McAllister 2018). Accordingly, we should expect a gender gap in turnout in second-order elections. We also 
discuss other potential explanations of sex inequality in voter turnout and explain why they are unlikely to account for the difference between first-order and second-order elections. We subsequently test these explanations along with our main hypothesis by including control variables corresponding to the various explanatory factors.

We validate our theory with a systematic study of voting in different types of elections using two different cross-national datasets that span 26 countries and include 42,415 respondents. Our analysis proceeds in three steps. First, we examine whether there is a gender gap in turnout in different types of elections. Our analyses confirm that there is no gender gap in first-order elections, which are typically elections to the national parliament. In contrast, turnout tends to be higher among men in second-order elections, which comprise most subnational and supranational elections. Second, we use a non-linear adaptation of the BlinderOaxaca decomposition and logistic regressions to ascertain the sources of these gender gaps. The results corroborate our expectations: the turnout gaps in second-order elections reflect sex differences in political interest and political knowledge. Third, we conduct additional analyses to show how political interest and political knowledge explain the varying effects of sex on voter turnout across election types.

\section{Theory and Hypotheses}

The political science literature shows that sex inequalities persist in some non-electoral forms of political participations such as protest participation, political persuasion and campaigning (e.g. Inglehart and Norris 2003; Norris 2007; Coffé \& Bolzendahl 2010; Ondercin and Jones-White 2011; Beauregard 2014; Córdova and Rangel 2017). However, it is generally considered that women vote at the same rate as men in most advanced democracies (Verba, Burns and Schlozman 1997; Norris 2002; Mayer 2010). As a result, relatively little recent research tackles sex differences in voter turnout (but see Harell 2009). Interestingly, two studies 
have reported as a secondary finding that women participate less than men in European Parliament elections (Soderlund et al. 2011; Blais and Kostelka 2015). Women are also less likely than men to vote in Swiss federal elections (Engeli et al. 2003; Stadelmann-Steffen and Koller 2014). ${ }^{2}$ We argue that these cases are not exceptions but reflect a broader pattern of sex differences in participation between less important (second-order) and more important (firstorder) elections.

It has long been recognized that voter turnout depends heavily on psychological engagement with politics, particularly in less important elections (Campbell 1960; Campbell et al. 1960). According to this line of thought, the electorate can be divided into core voters, who are politicised and interested in politics, and peripheral voters, who are less psychologically involved in politics. While core voters go to the polls in most circumstances, peripheral voters "have less intrinsic interest in political matters" and vote "only when there is strong stimulation to do so" (Campbell 1960: 409).

Perhaps the most important criterion that determines the importance of an election in an established democracy is election type. While voter turnout typically varies by only three percentage points from one election to another election of the same type within countries (Blais 2007), the differences across election types often exceed ten percentage points. ${ }^{3}$ Except for a few specific cases discussed below, participation is considerably lower in subnational and supranational elections. For a number of reasons, these electoral contests tend to be "low-

\footnotetext{
${ }^{2}$ Córdova and Rangel's (2017) results suggest that the traditional gender gap may still exist in national elections. However, their Table A1 in the Electronic Appendix reveals that this is the case only in young democracies and it is neither substantively nor statistically significant in any Western democracy but Switzerland.

${ }^{3}$ For instance, in those countries and elections that we study below, the average within-country variance in official voter turnout rates across election types reaches 12.5 percentage points (elections covered by the Making Electoral Democracy Work project) and 26.1 percentage points (elections covered by the European Election Study).
} 
stimulus elections" (or second-order) when compared to "high-stimulus" (first-order) national elections (Reif and Schmitt 1980). The stakes are lower in the former. The policy competence of municipal, regional and European authorities is usually limited and, in most cases, the central authorities have a preponderant say on the most important policy issues and manage the greatest share of the public budget (Moravscik 2002). Moreover, in European Parliament (EP) elections the link between election outcomes and policy seems particularly tenuous (Hix 2006). Partly as a result of lower stakes, subnational and supranational elections tend to generate less party mobilisation and parties' campaign expenditures are usually much lower than in national elections (van Klingeren et al. 2015). At the same time, media coverage is considerably less intense than in national contests (de Vreese, Lauf and Peter 2007). In short, subnational and supranational elections provide citizens with an environment that is less conducive to electoral participation: the stakes are less clear, information is scarcer and social pressure to participate is weaker.

The less voter friendly environment of second-order elections should particularly impact citizens who are less interested in politics. Their feeble interest translates into a weak intrinsic motivation to vote and a lack of information. If mobilisation by politicians, the media and/or the community is weak, such peripheral voters can be expected to turn out in smaller numbers. The act of voting in second-order elections is more demanding: it is costlier and less rewarding. Citizens with little interest in politics are likely to vote in the most important elections while eschewing in large numbers other electoral contests where the incentives to participate are weaker. This implies that the differences in voter turnout between first-order and second-order elections should be predominantly driven by variable participation on the part of individuals with low interest in politics. From this perspective, voter "turnout in any specific [type of] election is largely a question of how many of the less interested [...] make the effort to vote." (Campbell 1960: 400). 
The degree of psychological involvement in politics can be measured in two ways. The more traditional method relies on self-reported political interest. One of the strongest individual-level predictors of voter turnout (Brady et al. 1995; Blais 2000), interest in politics is typically acquired in the process of socialisation and remains largely stable throughout one's lifetime (Cambpell et al. 1960; Prior 2010). As a result, variation in turnout across election types is unlikely to reflect variation in the degree of subjective political interest but rather variation in the degree to which subjective interest matters for participation.

Another measure of psychological involvement in politics is political knowledge, which has been found to foster voter turnout even after controlling for subjective political interest (Coulson 1999; Milner 2002: 43-44; Larcinese 2007; Ondercin and Jones-White 2011). This measure is different in nature since it is typically more context specific. Less politicised citizens may be relatively knowledgeable about national-level political actors, thanks to exposure to nationwide media, and yet show a sketchier grasp of subnational or supranational politics. Such variation in political knowledge across levels of government reflects at least two attributes that matter for voter turnout: the level of attention paid to the given political arena at a particular moment of time and the availability of information. In contrast to subjective political interest, variation in voter turnout is likely to be driven by variation in the amount of political knowledge and less so by variation in the effect of political knowledge.

The scientific literature consistently shows that, despite the disappearance of gender gaps in turnout in national elections, when asked in surveys, women express lower levels of political interest and give fewer correct answers to political knowledge questions than men (Inglehart 1981; Verba et al. 1997, Burns et al. 2001; Gidengil et al. 2004; Kittilson and Schwindt-Bayer 2010; Fraile 2014, Dassonneville and McAllister 2018). Although this may be 
partially due to a gender bias in measurement ${ }^{4}$ and does not necessarily apply to all subdimensions of political interest (Campbell and Winters 2008; Coffee 2013), it is widely held that these differences are generally nonetheless real and originate in the process of political socialisation (Bennett and Bennett 1989; Verba, Burns and Schlozman 1997: 1070; Norris 2007: 733-735). This implies that women are overrepresented among peripheral voters who have a lower propensity to vote in the absence of a strong stimulus (see also Harell 2009). Consequently, although women may vote at the same rates as men in national electoral contests, where the environment is the most conducive to participation, a gender gap can be expected in second-order elections, where psychological engagement in politics matters more. To some extent, voting in second-order elections is likely to resemble engagement in other, more demanding, forms of political participation such as attending public meetings or joining in a protest, where women still participate less than men largely due to their lower levels of political interest and political knowledge (Verba, Burns and Schlozman 1997; Ondercin and Jones-White 2011).

However, not all non-national elections are second-order and not all national elections are first-order (see Schakel and Jeffery 2013). For instance, in subnational entities with a strong regional identity, such as Catalonia or Quebec, the question of regional autonomy and the presence of regional parties may increase the perceived stakes and hence interest in the regional

\footnotetext{
${ }^{4}$ Mondak and Anderson (2004) estimate that as much as half of the gender gap in political knowledge is attributable to sex differences in the propensity to guess. Other scholars have suggested that conventional measures systematically underestimate women's political knowledge because they implicitly limit the scope of politics to the traditional arenas of electoral and legislative politics (Smiley 1999). However, even if political knowledge questions are subject to these gender biases, this does not undercut their usefulness for predicting voter turnout since, to some extent, voting is similar to answering a knowledge-based question: if women are unsure about their preference, they may decide not to vote.
} 
election. This will be reflected in a voter turnout that is as high or even higher than in national elections. In such cases, regional elections qualify as first-order elections and we can expect women to be as likely to vote as men. Conversely, some national contests may be much less mobilising because their outcomes are not consequential. This is exemplified by Switzerland, where the most important decisions are taken through referenda and government composition is determined by a long-term power-sharing deal (Franklin 2004, Blais 2014). In such secondorder national elections, peripheral voters participate less than core voters and so we can expect women to vote at lower levels than men, since they are more likely to be peripheral voters.

Hypothesis 1: Women vote at the same rates as men in first-order elections but they vote at lower rates in second-order elections.

Hypothesis 2: Women vote less than men in second-order elections because they are less psychologically engaged in politics.

Psychological engagement in politics is not the only potential source of sex differences in voter turnout. The scientific literature advances at least three other types of explanation for why women may be less politically active than men (Norris 2007). They pertain to gendered political practices and institutions, a lack of resources, and fewer opportunities to be mobilised. However, in most cases, these explanations are unlikely to account for the sex difference in voter turnout between first-order and second-order elections.

From the perspective of the current research question, the first factor is of little help. In the case of EP elections, the gender gap is unlikely to be due to male-dominated institutions or practices. In all EU member states, EP elections are run using proportional representation, which tends to be favourable to female candidates (Kittilson and Schwindt-Bayer 2010). 
Accordingly, EP elections have systematically yielded a significantly higher share of female deputies than national elections and "the European Parliament is heralded as one of the most gender-equal elected bodies in the world" (Fortin-Rittberger and Rittberger 2014: 1).

The potential for sex differences in resources to explain the variation in the gender gap in voter turnout across election types is also limited. Burns et al. (2001) find that the availability of free time has no effect on the political participation of women or men, and that women who work full-time and have children are actually more likely to participate than their stay-at-home counterparts. Similarly, even though education, along with age, is the most important individual predictor of voter turnout (Blais 2000: 52), in most developed countries women today have higher average levels of educational attainment than men (cf. Pekkarinen 2012). Moreover, a seminal study of the resource model of political participation concludes that "political interest is much more important than resources if our main project is to explain voting turnout” (Brady at al. 1995: 283).

The third factor is party mobilisation. When media coverage is sparser, as it typically is in second-order elections, the burden of direct mobilisation falls upon political parties. Given that women are less likely than men to belong to a political party or to be involved in political networks (Norris 2007), they may be more difficult to reach. As a result, men may be more likely than women to be contacted by canvassers in second-order elections. In the same vein, women are less likely to experience indirect mobilisation, given the gendered nature of associational involvement and social networks. Women are more likely to belong to associations that relate to the traditional domains of the home and community and that reinforce their private sphere roles (Norris and Inglehart 2005). Importantly, there is less discussion of politics in these female-dominated associations (Gidengil et al. 2005) and so women are less likely to be exposed to mobilising influences. Similarly, women's informal social networks 
tend to be less diverse than men's (Gidengil et al. 2006). Whether these differences are sufficiently strong to account for a gender gap in second-order elections is an open question.

\section{Data and Methods}

The following empirical analyses employ two datasets. The first comes from the Making Electoral Democracy Work project (MEDW, Blais 2010; Stephenson et al. 2017). It is particularly suitable for tackling our main research question since, in contrast to most available alternatives, it provides the same kind of information about voter behaviour in elections at different levels of government (national, subnational and supranational) and thus allows for comparisons across election types. It contains survey data from five countries (Canada, France, Germany, Spain and Switzerland), which were gathered between 2010 and 2015. In each country, two sub-national administrative units (referred to here as 'regions') were studied. ${ }^{5}$ Altogether, we use twenty-three samples: nine from national elections, nine from subnational elections and five from supranational elections. ${ }^{6}$ Another major advantage of these data is that the surveys are short two-wave panels, conducted about one week before and one week after the given election. All the independent variables tested below were measured before the election whereas the dependent variable was measured afterwards. This allows for much greater confidence in the direction of causality. The other dataset is the 2014 European Election Study (EES) (Schmitt et al. 2016), which enables us to test our findings on a larger pool of 24

\footnotetext{
${ }^{5}$ The samples are from Ontario and Quebec in Canada, Île de France and Provence in France, Lower Saxony in Germany, Madrid and Catalonia in Spain; and Lucerne and Zürich in Switzerland.

${ }^{6}$ The complete list can be found in the Electronic Appendix.
} 
EU member states. ${ }^{7}$ Another key advantage of the ESS data is that they allow for comparing the same individuals in both national and European elections (but, importantly, not subnational elections).

We distinguish five types of elections: national elections, subnational elections in Catalonia and Quebec, subnational elections in other regions, supranational elections, and Swiss elections. ${ }^{8}$ As discussed above, we expect voters to consider the first two types of electoral contests (national elections, and subnational elections in Catalonia and Québec) to be more important than the other types. This is confirmed empirically in the MEDW surveys, which asked citizens to rate the importance of the current election on a 0 to 10 scale. Table 1 shows that subnational elections in Catalonia and Quebec are seen to be as important as national elections (i.e. the reference category). In contrast, the perceived importance of the other three types is both substantively and significantly lower. Consequently, we refer to the first two election types as "first-order" and the other three as "second-order". We expect women to vote at lower rates than men in second-order elections since participation in less important elections is costlier and less gratifying for those who are less psychologically engaged in politics. It should be emphasized that our theory does not postulate that perceived importance differs by sex, and we find no sex difference. ${ }^{9}$

\footnotetext{
${ }^{7}$ The 24 countries are Austria, Bulgaria, Croatia, Czech Republic, Denmark, Estonia, Finland, France, Germany, Hungary, Ireland, Italy, Latvia, Lithuania, Malta, Netherlands, Poland, Portugal, Romania, Slovakia, Slovenia, Spain, Sweden, and the United Kingdom. Countries that use compulsory voting are excluded.

${ }^{8}$ Drawing on earlier research (Blais 2014), we expect national elections in Switzerland to be less relevant than in other countries and we therefore pool them together with Swiss subnational elections. This analytical choice is further validated by Table EA 6 in the Electronic Appendix, which shows that the estimated gender gap is of comparable magnitude in both election types.

${ }^{9}$ We reran the analysis presented in Table 1 including an interaction between sex and election types (see Table EA 5). The results reveal that women rate all elections as less important than men do. Women may be more
} 
We first measure the impact of sex on voter turnout in each type of election (Hypothesis 1). ${ }^{10}$ Then, we test Hypothesis 2 via a non-linear decomposition of the effect of sex. Finally, we explore in greater detail the variation in the explanatory factors by sex and election type.

\section{Table 1 Perceived Importance of Election by Election Type (MEDW Data)}

\begin{tabular}{cc}
\hline Election type & $\mathrm{b}$ \\
\hline Subnational & -0.24 \\
& $(0.10)^{*}$ \\
Supranational & -2.02 \\
& $(0.10)^{* * *}$ \\
Swiss elections & -1.02 \\
Catalonia \& Québec: & $(0.09)^{* * *}$ \\
Subnational & 0.08 \\
& $(0.12)$ \\
Constant & 7.12 \\
\hline Observations & $(0.06)^{* * *}$ \\
$R^{2}$ & 19,239 \\
\hline
\end{tabular}

Note: MEDW data. OLS Regression. The dependent variable is importance of the current election (scale ranged from 0 to 10). The reference category is National Elections. The category Subnational does not include subnational elections in Catalonia and Québec, which are a separate category. Robust standard errors in parentheses. ${ }^{+} p<0.10,{ }^{*} p<0.05,{ }^{* *} p<0.01,{ }^{* * *} p<0.001$.

In the MEDW dataset, Interest is a self-reported rating of general political interest on a scale from 0 (no interest in politics) to 10 (strong interest). To facilitate comparison with other

\footnotetext{
interested in local politics than men as some studies have found (Coffé 2013), but they do not rate local elections as more important than men do or more important than national elections (in both cases, it is rather the opposite).

${ }^{10}$ The data are weighted to correct for over-reporting and correspond to the real voter turnout rate. This weighting has no impact on the substantive results of our study. More generally, it is true that a sex difference in overreporting could, in theory, affect our analysis. We cannot address this directly since we do not have a validated measure of voter turnout at our disposal. However, previous studies of validated voter turnout (Karp and Brockington 2005) and survey experiments (Morin-Chassé et al. 2017) did not find consistent or statistically significant sex differences in over-reporting.
} 
variables, we divide it by ten. Political knowledge is evaluated by asking respondents to match pictures of party leaders competing in the election with their respective party names. In each survey, there were typically 5 competing parties and 10 pictures ( 5 pictures of party leaders and 5 pictures of other political personalities). The resulting variable Knowledge gives the proportion of correct matches (between 0 and 1). In the EES data, Interest is a 4-point scale recoded to vary between 0 and 1 . The measure of political knowledge gives the share of correct answers to two factual questions about the European Union (whether it is true that "Switzerland is a member of the EU" and "Each Member State elects the same number of representatives to the European Parliament") and two questions about the national political system (whether "there are $[150 \%$ of the correct number $]$ members in the lower house of national parliament" and whether "[name of the head of government] belongs to [the name of the correct party]"). When compared to the MEDW measure, the EES indicators tap knowledge that is less electionspecific and more likely to be acquired in school, thus providing a weaker measure of psychological involvement in politics.

Controls are included for resources and exposure to mobilisation in order to test for alternative explanations, as discussed in the previous section. In the MEDW data, resources include Age (a continuous variable), Tertiary education (a dummy variable) and the fact of having Children (a dummy variable). ${ }^{11}$ Mobilisation corresponds to dummies that ascertain whether the respondent was contacted by a political party (Party) or was encouraged to vote for a political party by a friend (Friend), family member (Family) or spouse (Spouse). In the EES data, in addition to the variables Age, Tertiary education and Children, which are measured exactly the same as in the MEDW data, resources include dummy variables pertaining to employment: Employed and Self-employed (the reference category being those

\footnotetext{
${ }^{11}$ Unlike the EES data, the MEDW unfortunately does not offer variables pertaining to employment.
} 
who declare no formal employment). The data also offer a ten-point social status scale (recoded to vary between 0 and 1), where the extreme points correspond to the "lowest" and "highest" levels in society, respectively. Mobilisation is operationalized through two dummies: Trade union member and Party closeness. The latter is coded as 1 for those who report feeling close to a political party.

Controls are also included for attachment to the given level of government, using the extent to which citizens consider voting in the current election to be a civic duty on a scale from 0 to 1 in the case of the MEDW data ${ }^{12}$ and two dummy variables indicating attachment to the European and national levels of government, respectively, in the case of the EES data. More details and descriptive statistics are presented in the Appendix.

\section{Findings}

\section{Election Type and the Gender Gap in Voter Turnout}

To test our first hypothesis regarding the presence of a gender gap in voting in secondorder elections, we run a logistic regression for each election type. The dependent variable is reported turnout and the main independent variable is the dummy Female. All models also include election-region (or, in the EES, election-country) dummy variables. Our interpretation is based on the average marginal effects (AME). These are average changes in the probability of voting resulting from a one-unit change in the independent variable and are estimated using the observed values method (Mood 2010).

The results presented in Table 2 clearly validate our expectations. The analyses of the MEDW data show that the effect of sex in first-order elections is substantively small and

\footnotetext{
12 The use of a more direct question on attachment (Q43A-D) yields substantively similar results but, since the variable is available only for a subset of surveys, we opt for the civic duty question.
} 
statistically insignificant. In contrast, women participate substantially less in all types of second-order elections: subnational, supranational, and Swiss. In those electoral contests, the gender gap in the predicted probability of voting reaches 8,9 , and 16 percentages points, respectively. We show in the Electronic Appendix that these differences also largely hold when the data are broken down by country or region. ${ }^{13}$

The EES data, which allow us to compare the participation of the same individuals in different contests, give a similar picture. In national elections, there is no sex difference in participation, but the difference is both substantively and statistically significant in supranational elections. The substantive magnitude of this difference is smaller than in the MEDW data, which is not surprising given that EES data contain a broader sample of countries across which sex inequality varies. We explore this variation in Figure 1, which plots the estimates of the gender gap in voter turnout in national and supranational election by country. In addition, the figure plots the sex difference in the drop-off between national and supranational elections, i.e. the difference between the share of women and the share of men who vote in national elections but do not vote in EP elections. Following our theory, we distinguish two groups of countries: those with a large sex difference in political interest and those with a small difference. ${ }^{14}$ In the latter group, which includes mostly North European countries, women seem to vote at slightly higher rates than men and there is typically little

\footnotetext{
${ }^{13}$ See Table EA 6. The only exception is the Madrid region where no significant gender gap was recorded in subnational elections.

${ }^{14}$ We use political interest since the subsequent analyses show that it accounts for a greater share of the gender gap in voter turnout than political knowledge. The small sex difference group corresponds to the top $20 \%$ of countries with a substantively weak $(<0.04)$ and, typically, statistically insignificant sex difference on the $0-1$ scale of political interest.
} 
difference between the national and supranational levels. ${ }^{15}$ Likewise, the differences in the national-supranational drop-off tend to be substantively small and statistically insignificant. By contrast, in the former, more sex-differentiated group, women tend to vote at lower rates than men in supranational elections but there is no consistent sex difference in national elections. By the same token, the gender differences in drop-off rates tend to be larger and, in many cases, statistically significant. This suggests that, in those countries in which women have less interest in politics than their male counterparts, they vote at lower rates than men in supranational elections.

Figure 1 Gender Gap in Voter Turnout by Country (EES data)

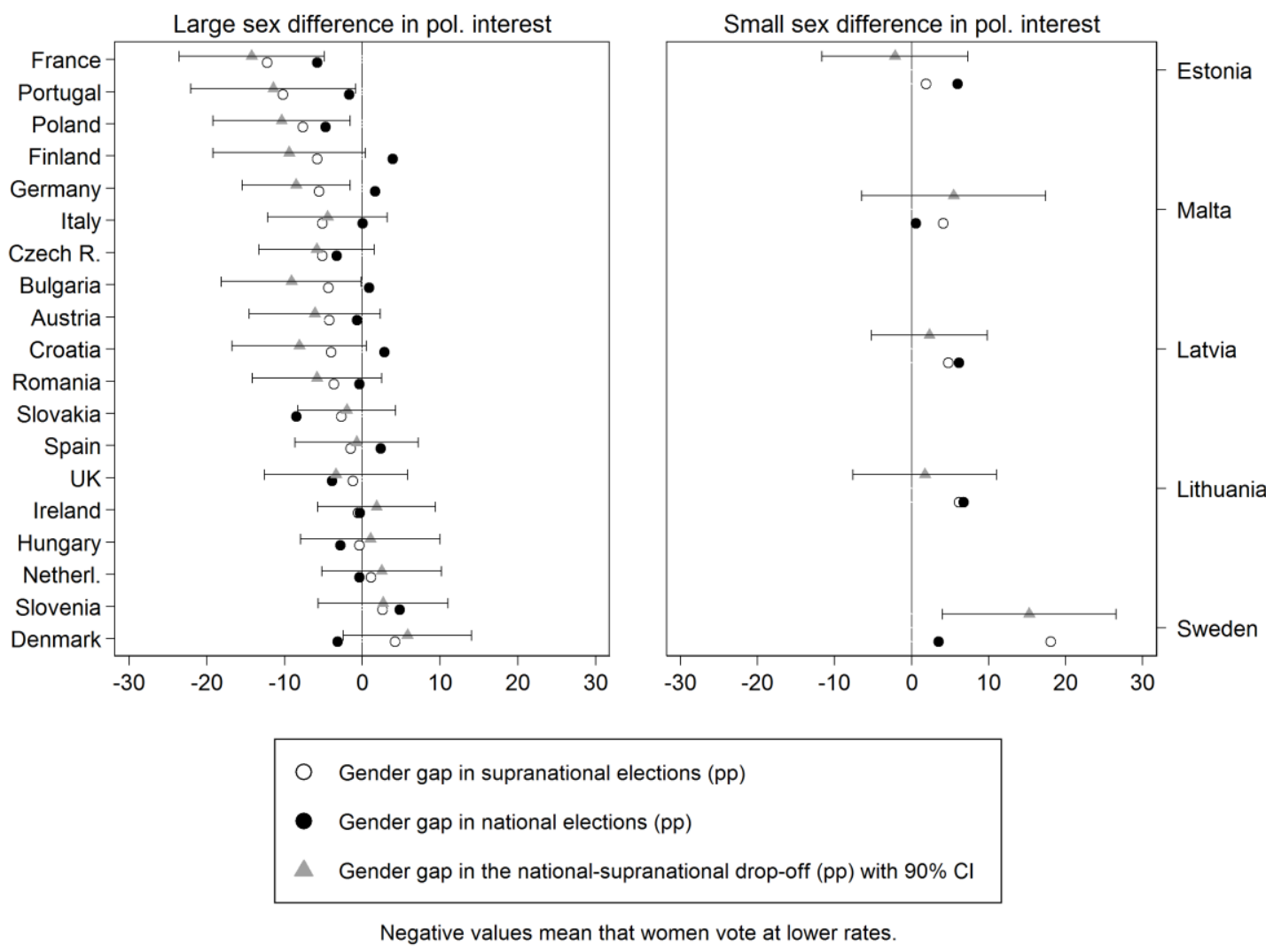

\footnotetext{
${ }^{15}$ An important exception is Sweden where women vote at higher rates than men in supranational elections.
} 
Table 2 Gender Gap in Voter Turnout by Election Type (Hypothesis 1)

\begin{tabular}{|c|c|c|c|c|c|c|c|}
\hline & \multicolumn{5}{|c|}{ MEDW Data } & \multicolumn{2}{|c|}{ EES Data } \\
\hline & $\begin{array}{c}(1) \\
\text { National }\end{array}$ & $\begin{array}{c}\text { (2) } \\
\text { Catalonia } \\
\text { \& Québec: } \\
\text { Subnational }\end{array}$ & $\begin{array}{c}\text { (3) } \\
\text { Subnational }\end{array}$ & $\begin{array}{c}\text { (4) } \\
\text { Supranational }\end{array}$ & $\begin{array}{c}(5) \\
\text { Swiss }\end{array}$ & $\begin{array}{c}(6) \\
\text { National }\end{array}$ & $\begin{array}{c}\text { (7) } \\
\text { Supranational }\end{array}$ \\
\hline Female & $-0.02(0.02)$ & $-0.04(0.04)$ & $-0.08^{* *}(0.03)$ & $-0.09^{* * * *}(0.02)$ & $-0.16^{* * *}(0.02)$ & $-0.01(0.01)$ & $-0.04^{* * *}(0.01)$ \\
\hline Election-region dummies & Yes & Yes & Yes & Yes & Yes & Yes & Yes \\
\hline Observations & 6741 & 1550 & 3895 & 4127 & 3467 & 22635 & 22635 \\
\hline Pseudo $R^{2}$ & 0.01 & 0.00 & 0.02 & 0.01 & 0.03 & 0.03 & 0.04 \\
\hline $\begin{array}{l}\text { Predicted voting rate of } \\
\text { male respondents }\end{array}$ & 0.67 & 0.74 & 0.61 & 0.51 & 0.54 & 0.68 & 0.45 \\
\hline
\end{tabular}

Note: Logit Regression. Average marginal effects (AME) with robust standard errors in parentheses. ${ }^{+} p<0.10,{ }^{*} p<0.05,{ }^{* *} p<0.01,{ }^{* * *} p<0.001$. 
Of course, we cannot draw far-reaching conclusions about individual cases since the estimations plotted in Figure 1 suffer from noise due to sampling variance and relatively small sample sizes. However, taken together, these patterns confirm that the aggregated results presented in Table 2 are not driven by a few extreme country-case studies. They also provide some preliminary evidence for Hypothesis 2 , which we test with more advanced tools in the next section.

\section{Decomposing the Gender Gap in Voter Turnout in Second-Order Elections}

To test Hypothesis 2, we employ an adaptation of the Blinder-Oaxaca decomposition for non-linear regression models that was proposed by Fairlie (2005). ${ }^{16}$ Decomposition is a classic method for the analysis of political and economic inequalities in terms of sex or race (Blinder 1973, Oaxaca 1973, Dow 2009, Kim 2010). Starting from a regression analysis, it decomposes differences in mean outcomes across two groups into two parts: explained and unexplained (see Equation 1). The explained part corresponds to group differences in the levels of the independent variables and the unexplained part to group differences in the magnitude of regression coefficients (as well as the constant and the contributions of unobserved variables, see Fairlie 2005: 3). In the context of the current research question, the difference in mean outcomes that we decompose is the difference between men's and women's average voting rate as shown in Table 2. The explained part indicates how much of the gender gap in voter turnout is due to unequal endowments in the factors we discussed above. ${ }^{17}$ If Hypothesis 2 is

\footnotetext{
${ }^{16}$ We executed the decomposition via the Stata package Fairlie (Jann 2008).

${ }^{17}$ Following other studies using the decomposition methods (see Jones 1983, Fairlie 2005), we do not interpret the unexplained part because of its ambiguity.
} 
correct, sex differences in political interest and political knowledge account for most of the gap.

\section{Equation 1 The non-linear decomposition proposed by Fairlie 2005}

$$
\bar{Y}^{M}-\bar{Y}^{W}=[\underbrace{\left[\sum_{i=1}^{N^{M}} \frac{F\left(X_{i}^{M} \hat{\beta}^{*}\right)}{N^{M}}-\sum_{i=1}^{N^{W}} \frac{F\left(X_{i}^{W} \hat{\beta}^{*}\right)}{N^{W}}\right]}_{\text {Explained Part }}+[\underbrace{\left[\sum_{i=1}^{N^{M}} \frac{F\left(X_{i}^{M} \hat{\beta}^{M}\right)}{N^{M}}-\sum_{i=1}^{N^{M}} \frac{F\left(X_{i}^{M} \hat{\beta}^{W}\right)}{N^{M}}\right]}_{\text {Unexplained Part }}
$$

Note: The M and W superscripts stand for Men and Women. The function F is logit.

The decomposition necessitates the choice of reference regression coefficients that are applied to the explained part of the equation. Like Fairlie 2005, we opt for the regression coefficients $\hat{\beta}^{*}$ from a pooled regression model (including both male and female respondents) ${ }^{18}$ but the alternative use of male $\left(\hat{\beta}^{M}\right)$ or female coefficients $\left(\hat{\beta}^{W}\right)$ yields very similar results.

The results of the decomposition are displayed in Tables 3 (MEDW data) and 4 (EES data). ${ }^{19}$ They show that differences in endowments explain most of the gender gap for all three types of second-order election. The share of the explained part varies from $68 \%$ in Swiss elections to $102 \%$ in subnational elections. The latter share suggests that, if women and men had exactly the same levels for all the independent variables included in the regression model, women's voting rates would be slightly higher than men's in non-Swiss subnational elections.

\footnotetext{
${ }^{18}$ Following Fairlie 2005 (p. 309, footnote 8; see also Jann 2008: 458), the pooled model used for extracting the coefficients contains the group dummy (Female).

${ }^{19}$ Note that, as the decomposition includes only individuals with non-missing values on all the independent variables, the measured gender gap is slightly larger than in Table 2.
} 
Table 3 The Non-Linear Decomposition of the Effect of Sex (MEDW)

\begin{tabular}{|c|c|c|c|c|c|c|}
\hline Election type & \multicolumn{2}{|c|}{ Subnational } & \multicolumn{2}{|c|}{ Supranational } & \multicolumn{2}{|c|}{ Swiss } \\
\hline \multicolumn{7}{|c|}{ Gender gap to explain } \\
\hline Turnout: men & \multicolumn{2}{|c|}{0.627} & \multicolumn{2}{|c|}{0.530} & \multicolumn{2}{|c|}{0.551} \\
\hline Turnout: women & \multicolumn{2}{|c|}{0.534} & \multicolumn{2}{|c|}{0.424} & \multicolumn{2}{|c|}{0.398} \\
\hline Gender gap & \multicolumn{2}{|c|}{0.092} & \multicolumn{2}{|c|}{0.106} & \multicolumn{2}{|c|}{0.153} \\
\hline \multicolumn{7}{|c|}{ Total contributions } \\
\hline Part & Contribution & $\begin{array}{c}\% \text { of } \\
\text { gender gap }\end{array}$ & Contribution & $\begin{array}{c}\% \text { of } \\
\text { gender } \\
\text { gap }\end{array}$ & Contribution & $\begin{array}{c}\% \text { of } \\
\text { gender gap }\end{array}$ \\
\hline Explained & 0.094 & 101.9 & 0.082 & 77.1 & 0.105 & 68.4 \\
\hline Unexplained & -0.002 & -1.9 & 0.024 & 22.9 & 0.048 & 31.6 \\
\hline \multicolumn{7}{|c|}{ Individual contributions to the explained part } \\
\hline Variable & Contribution & $\begin{array}{c}\% \text { of the } \\
\text { explained } \\
\text { part }\end{array}$ & Contribution & $\begin{array}{c}\% \text { of the } \\
\text { explained } \\
\text { part }\end{array}$ & Contribution & $\begin{array}{c}\% \text { of the } \\
\text { explained } \\
\text { part }\end{array}$ \\
\hline Interest in politics & $0.031^{\text {***** }}$ & 33.5 & $0.024^{* * * *}$ & 29.8 & $0.040^{* * * *}$ & 38.0 \\
\hline Knowledge & $0.032^{* * * *}$ & 33.5 & $0.030^{* * * *}$ & 37.2 & $0.047^{* * * *}$ & 45.3 \\
\hline Age & $0.007^{* * * *}$ & 7.1 & $0.006^{* * * *}$ & 7.8 & $0.001^{* * *}$ & 1.2 \\
\hline Tertiary education & 0.004 & 4.2 & 0.001 & 1.0 & 0.008 & 7.8 \\
\hline Children & 0.000 & -0.4 & $-0.005^{* * * *}$ & -5.8 & -0.001 & -1.2 \\
\hline Mobilisation: Party & 0.000 & -0.5 & 0.003 & 3.8 & 0.000 & 0.1 \\
\hline Mobilisation: Friend & -0.002 & -1.8 & -0.001 & -0.7 & 0.001 & 1.3 \\
\hline Mobilisation: Family & $-0.002^{+}$ & -2.2 & 0.000 & -0.6 & $-0.004^{+}$ & -3.4 \\
\hline Mobilisation: Spouse & 0.000 & 0.1 & $0.005^{* * * *}$ & 5.8 & -0.001 & -0.9 \\
\hline Duty to vote & $0.015^{* * *}$ & 15.8 & $0.017^{* * * *}$ & 20.8 & $0.009^{* * * *}$ & 8.5 \\
\hline Region dummy 1 & 0.004 & 3.8 & 0.000 & 0.2 & 0.000 & -0.1 \\
\hline Region dummy 2 & 0.000 & 0.2 & 0.000 & -0.2 & $0.003^{* *}$ & 2.5 \\
\hline Region dummy 3 & 0.000 & 0.5 & 0.000 & 0.1 & 0.000 & 0.0 \\
\hline Region dummy 4 & $0.005^{* *}$ & 5.8 & 0.000 & 0.5 & & \\
\hline $\mathrm{N}$ & 37 & & 39 & & 33 & \\
\hline
\end{tabular}

Note: Regional dummies are Lower Saxony (1), Ontario (2), Marseille (3), Madrid (4), and Paris (reference) in the case of subnational elections; Provence (1), IDF (2), Lower Saxony (3), Madrid (4), and Catalonia (reference) in the case of supranational elections; and Lucerne national (1), Lucerne subnational (2), Zürich national (3) and Zürich subnational (reference) in the case of case Swiss elections. ${ }^{+} p<0.10,{ }^{*} p<0.05,{ }^{* *} p<0.01,{ }^{* * *} p<0.001$. 
Table 4 The Non-Linear Decomposition of the Effect of Sex (EES Data)

\begin{tabular}{|c|c|c|}
\hline Turnout: men & \multicolumn{2}{|c|}{0.450} \\
\hline Turnout: women & \multicolumn{2}{|c|}{0.400} \\
\hline Gender gap & \multicolumn{2}{|c|}{0.044} \\
\hline \multicolumn{3}{|c|}{ Total contributions } \\
\hline Part & Explained & $\begin{array}{l}\% \text { of } \\
\text { gender } \\
\text { gap }\end{array}$ \\
\hline Explained part & 0.051 & $116 \%$ \\
\hline Unexplained part & -0.008 & $-18.2 \%$ \\
\hline \multicolumn{3}{|c|}{ Individual contributions to the explained part } \\
\hline Variable & Contribution & $\begin{array}{c}\% \text { of the } \\
\text { explained } \\
\text { part }\end{array}$ \\
\hline Interest & $0.041^{* * * *}$ & 93.3 \\
\hline Knowledge (European) & $0.008^{* * * *}$ & 18.0 \\
\hline Age & $-0.007^{* * *}$ & -16.2 \\
\hline Tertiary education & $0.001^{*}$ & 3.0 \\
\hline Children & $0.001^{+}$ & 2.0 \\
\hline Employed & $0.002^{+}$ & 3.4 \\
\hline Self-employed & $0.002^{*}$ & 5.1 \\
\hline Social status & $0.002^{* * *}$ & 4.5 \\
\hline Trade union Member & $0.002^{* * * *}$ & 4.5 \\
\hline Party Closeness & $0.001^{\text {***** }}$ & 1.6 \\
\hline Attachment(Europe) & 0.000 & 1.6 \\
\hline Attachment (national) & 0.000 & -0.3 \\
\hline $\begin{array}{l}23 \text { Country Dummies } \\
\text { (total contribution) }\end{array}$ & -0.001 & -1.4 \\
\hline
\end{tabular}

Note: The reference category for country dummies is France. ${ }^{+} p<0.10,{ }^{*} p<0.05,{ }^{* *} p<0.01,{ }^{* * *} p<0.001$.

Importantly, the results strongly support Hypothesis 2. In all cases, interest in politics and political knowledge account for at least two-thirds of the explained part. Interestingly, in all types of elections in the MEDW data, the contributions of the two factors are comparable. The only exception is the EES data, where knowledge of European politics explains much less than interest in politics (the ratio is $18 \%$ to $93 \%$ of the explained part). This relatively weaker 
contribution of political knowledge is consistent with the less election-specific nature of the EES measure when compared to the MEDW measure (see Data and Methods).

With respect to the control variables, the only consistent and moderately strong contribution comes from women's tendency to consider voting in second-order elections as less of a duty than men. It accounts for $9 \%$ (Swiss elections) to $21 \%$ (supranational elections) of the explained part of the gender gap. The EES data nonetheless show that when perceptions of different levels of government are measured on a more general level they have virtually no explanatory power in terms of the gender gap in voter turnout.

To complement these analyses, we replicated logistic regressions of voter turnout from Table 2 incorporating, in turn, the control variables, and political interest and political knowledge as predictors. The results are presented in the Electronic Appendix (Tables EA 7 and 8) and, like the decomposition method, provide strong support for Hypothesis 2. In all types of second-order elections, the gender gap in voter turnout remains substantively and statistically significant in the presence of control variables, enabling us to rule out the alternative explanations discussed above. In contrast, the inclusion of political interest and political knowledge renders the gap negligible and statistically insignificant. ${ }^{20}$

All in all, the results clearly validate the prediction that unequal psychological engagement in politics is the major source of the gender gap in voter turnout in second-order

\footnotetext{
${ }^{20}$ The only exception are Swiss elections where the gap is still significant but decreases from 11 to 5 percentages points. This residual gap is probably due to the singularity of the history of female suffrage in Switzerland. As Swiss women were enfranchised at the federal level only in 1971, it is possible that the effect of the lower degree of psychological engagement in politics is reinforced by additional generational and cultural barriers to women's electoral participation.
} 
elections. In the next subsection, we explore in greater detail the distribution of psychological engagement by sex and by election type.

\section{Sources of the Gender Gap in Interest and Knowledge}

On average, men are more interested and know more about politics than women do. This is evident from the results presented in Table 5. Models 1 and 3 simply regress Interest and Knowledge on sex and indicate that women's scores are significantly lower in every case in both the MEDW and EES data. While interest, as expected, does not vary by election type (see Model 2), Model 4 (MEDW data) and the difference between Models 6a and 6b (EES data) corroborate our expectations and show that the gender gap in knowledge is larger in second-order elections.

The question that remains to be answered is why the discrepancy in psychological engagement in politics plays a smaller role in first-order than in second-order elections. The level of interest in politics is not election-specific but our theory predicts that this factor matters more in less mobilising contexts. When there are fewer incentives to vote, the impact of political interest (or lack of it) can be expected to increase. To demonstrate this empirically, we ran an additional analysis with the MEDW data, pooling all elections. We added a dummy variable for second-order elections and an interaction between the dummy and Interest (see Model 1 in Table EA 4 in the Electronic Appendix). 
Table 5 Levels of Interest in Politics and Political Knowledge by Sex

\begin{tabular}{|c|c|c|c|c|c|c|c|}
\hline \multirow[t]{3}{*}{ Dataset } & \multicolumn{4}{|c|}{ MEDW } & \multicolumn{3}{|c|}{ EES } \\
\hline & (1) & (2) & (3) & (4) & (5) & $(6 a)$ & (6b) \\
\hline & $\begin{array}{c}\text { Political Interest } \\
\text { b/se }\end{array}$ & $\begin{array}{c}\text { Political Interest } \\
\text { b/se }\end{array}$ & $\begin{array}{c}\text { Knowledge } \\
\text { b/se }\end{array}$ & $\begin{array}{c}\text { Knowledge } \\
\text { b/se }\end{array}$ & $\begin{array}{c}\text { Political Interest } \\
\text { b/se }\end{array}$ & $\begin{array}{c}\text { Knowledge } \\
\text { (national) } \\
\text { b/se }\end{array}$ & $\begin{array}{c}\text { Knowledge } \\
\text { (European) } \\
\text { b/se }\end{array}$ \\
\hline Female & $\begin{array}{c}-0.08^{* * *} \\
(0.01)\end{array}$ & $\begin{array}{c}-0.08^{* * *} \\
(0.01)\end{array}$ & $\begin{array}{c}-0.10^{* * *} \\
(0.01)\end{array}$ & $\begin{array}{c}-0.07^{* * *} \\
(0.01)\end{array}$ & $\begin{array}{c}-0.10^{* * *} \\
(0.01)\end{array}$ & $\begin{array}{c}-0.07^{\text {*** }} \\
(0.01)\end{array}$ & $\begin{array}{c}-0.11^{* * *} \\
(0.01)\end{array}$ \\
\hline $\begin{array}{l}\text { Female * Subnational in } \\
\text { Catalonia and Ouébec }\end{array}$ & & 0.01 & & -0.01 & & & \\
\hline & & $(0.02)$ & & $(0.02)$ & & & \\
\hline Female * Subnational & & $\begin{array}{l}-0.02 \\
(0.02)\end{array}$ & & $\begin{array}{l}-0.04^{+} \\
(0.02)\end{array}$ & & & \\
\hline Female * Supranational & & $\begin{array}{l}-0.01 \\
(0.02)\end{array}$ & & $\begin{array}{l}-0.04^{*} \\
(0.02)\end{array}$ & & & \\
\hline Female $*$ Swiss & & $\begin{array}{l}-0.00 \\
(0.02)\end{array}$ & & $\begin{array}{l}-0.06^{* * *} \\
(0.02)\end{array}$ & & & \\
\hline $\begin{array}{l}\text { Subnational in Catalonia } \\
\text { and Québec }\end{array}$ & & $-0.03^{+}$ & & $-0.04^{* *}$ & & & \\
\hline & & $(0.02)$ & & $(0.01)$ & & & \\
\hline Subnational & & $\begin{array}{c}0.02 \\
(0.01)\end{array}$ & & $\begin{array}{c}-0.19^{* * * *} \\
(0.01)\end{array}$ & & & \\
\hline Supranational & & $\begin{array}{l}-0.02^{+} \\
(0.01)\end{array}$ & & $\begin{array}{c}-0.50^{* * *} \\
(0.01)\end{array}$ & & & \\
\hline Swiss & & $\begin{array}{c}0.01 \\
(0.01)\end{array}$ & & $\begin{array}{c}-0.21^{* * *} \\
(0.02)\end{array}$ & & & \\
\hline Tertiary education & $\begin{array}{l}0.05^{* * *} \\
(0.01)\end{array}$ & $\begin{array}{l}0.05^{* * *} \\
(0.01)\end{array}$ & $\begin{array}{l}0.10^{* * *} \\
(0.01)\end{array}$ & $\begin{array}{l}0.09^{* * *} \\
(0.01)\end{array}$ & $\begin{array}{l}0.12^{* * * *} \\
(0.01)\end{array}$ & $\begin{array}{l}0.08^{* * *} \\
(0.01)\end{array}$ & $\begin{array}{l}0.14^{* * *} \\
(0.01)\end{array}$ \\
\hline Constant & $\begin{array}{c}0.62^{* * * *} \\
(0.01) \\
\end{array}$ & $\begin{array}{c}0.62^{* * * *} \\
(0.01) \\
\end{array}$ & $\begin{array}{c}0.61^{\text {**** }} \\
(0.01) \\
\end{array}$ & $\begin{array}{c}0.79^{* * * *} \\
(0.01) \\
\end{array}$ & $\begin{array}{c}0.46^{* * * *} \\
(0.01) \\
\end{array}$ & $\begin{array}{l}0.65^{* * * *} \\
(0.01) \\
\end{array}$ & $\begin{array}{l}0.64^{* * * *} \\
(0.01) \\
\end{array}$ \\
\hline Observations & 19016 & 19016 & 19016 & 19016 & 22635 & 22635 & 22635 \\
\hline $\mathrm{R} 2$ & 0.03 & 0.03 & 0.04 & 0.30 & 0.05 & 0.04 & 0.06 \\
\hline
\end{tabular}


Figure 2 Effect of Political Interest and Knowledge by Election Type
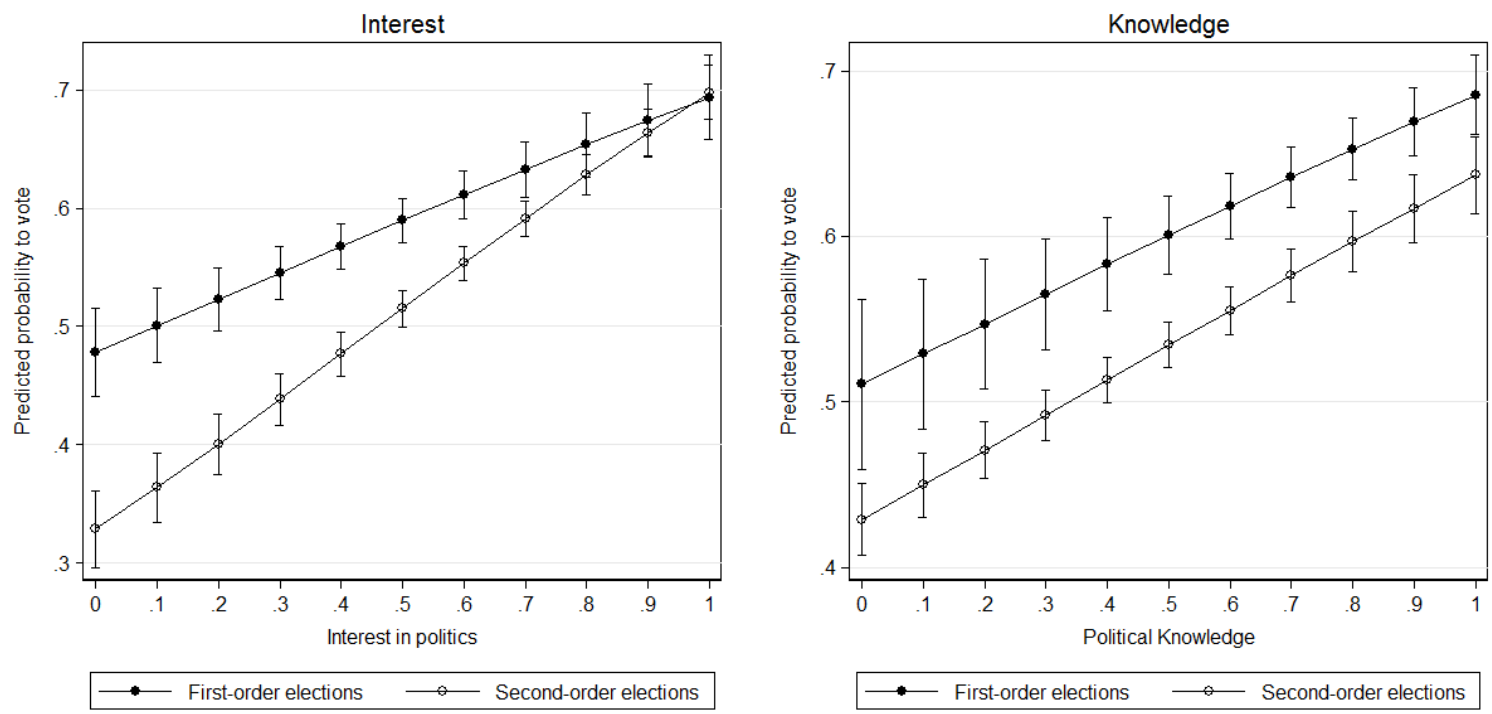

The left part of Figure 2 shows how the predicted probability of voting in first-order and second-order elections varies as a function of interest in politics. ${ }^{21}$ Fully in line with the theory first advanced by Campbell in 1960 (see above), the probability of voting is the same regardless of election type (slightly below 0.7 ) for high levels of interest in politics (score 1 on the $0-1$ scale). Moreover, as predicted, the weaker the interest, the larger is the difference in the probability of voting in first-order and second-order elections. For the lowest values of selfdeclared interest (0), the probability of voting is 48 percent in first-order elections but only 33 percent in second-order elections. The effect of political interest (the difference between 0 and 1) is thus much stronger in second-order elections (37 percentage points) than in first-order elections (22 percentage points). This explains why the gender gap in interest matters much more for voter turnout in second-order than in first-order elections. As an aside, this finding

\footnotetext{
${ }^{21}$ The figure draws on average marginal effects, i.e. the predicted probabilities are calculated for all individuals keeping these individuals' characteristics at their original values except for Interest (in Model 1), Knowledge (in Model 2), and Second-order elections.
} 
has implications for other disadvantaged groups that are less interested in politics such as young or less educated adults. ${ }^{22}$

In contrast to interest in politics and, as our theory predicts, political knowledge is an election-specific factor. We do not expect its effect to vary across election types and indeed it does not, as the right part of Figure 2 reveals (see also Model 2 in Table EA4). However, as we have noted above, the gender gap in knowledge is larger in second-order elections. Men are better able than women to identify the political leaders who run in the most important elections, but the discrepancy is even larger in less important contests.

\section{Discussion}

The findings confirm the conventional wisdom in political science that there is no gender gap in voter turnout in national elections in Western democracies. There is also no evidence of sex differences in subnational elections that are seen to be important by voters. The gap, however, still exists in second-order elections: subnational and supranational elections in most countries and regions, and both national and cantonal elections in Switzerland. The optimistic assessment that sex has no effect on turnout, dominant in the scientific literature, needs to be revisited. We have identified two reasons why women participate at lower rates than men in these contests.

First, as has been well documented by earlier work, women are less interested in politics. Drawing on classic political science theories, we show that this sex difference matters

\footnotetext{
${ }^{22}$ In the Electronic Appendix, we present additional analyses to show that young adults, parents and less educated respondents are more likely to drop out of voting in supranational elections and that this effect is diminished once political interest is controlled for (see Table EA 13).
} 
more in less mobilising contexts. In elections of lower importance, the fact of being (un)interested in politics matters more. With respect to subnational elections, our results show that even if women are more interested in local issues than men as earlier studies suggest, this does not compensate for the lack of interest in politics in general and does not prevent a gender bias in turnout. ${ }^{23}$ Second, as in the case of political interest, there seems to be a persistent sex difference in political knowledge that is detrimental to women's electoral participation. This difference is amplified in less important electoral arenas. Controlling for these two factors effectively eliminates (or, in the Swiss case, substantially reduces) the gender gap in voting in second-order elections.

The best way to eliminate the gender bias in second-order elections is to reduce the sex differences in political interest and political knowledge. This may prove particularly difficult given their tenacity despite the reduction of gender inequalities in other areas. As noted above, their roots are typically seen in the process of political socialisation. This means that change has to come essentially through generational replacement as a result of a transformation in the way that young people construct their political identity and learn about politics. Such a transformation may necessitate a targeted action plan by public authorities, whose benefits may extend well beyond full gender equality at the ballot box.

\section{References:}

Beauregard, Katrine (2014). 'Gender, political participation and electoral systems: A crossnational analysis', European Journal of Political Research 53:3, 617-634.

\footnotetext{
${ }^{23}$ As with supranational elections, the presence and degree of the gender gap in subnational elections is likely to vary cross-nationally as a function of gender differences in political interest and political knowledge (and also these elections' importance). For instance, in contrast to the countries studied here, Childs (2004) reports no gender gap in voter turnout in Great Britain's local elections.
} 
Bennett, Linda L. M. and Stephen Earl Bennett (1989). 'Enduring Gender Differences in Political Interest The Impact of Socialization and Political Dispositions', American Politics Quarterly 17:1, 105-122.

Blais, André (2000). To Vote or Not to Vote?: The Merits and Limits of Rational Choice Theory, Pittsburgh: University of Pittsburgh Press.

Blais, André (2007). 'Turnout in Elections', in Hans-Dieter Klingemann and Russell J. Dalton (eds). The Oxford Handbook of Political Behavior. Oxford: Oxford University Press, 621-635.

Blais, André (2010). 'Making Electoral Democracy Work', Electoral Studies 29:1, 169-170.

Blais, André (2014). 'Why is Turnout So Low in Switzerland? Comparing the Attitudes of Swiss and German Citizens Towards Electoral Democracy', Swiss Political Science Review 20:4, 520-528.

Blais, André and Filip Kostelka (2015). 'The Decision to Vote or Abstain in the 2014 European Elections', European Journal of Social Sciences :53-1, 79-94.

Blinder, Alan (1973). 'Wage Discrimination: Reduced Form and Structural Estimates', Journal of Human Resources 8:4, 436-455.

Brady, Henry E., Sidney Verba, and Kay Lehman Schlozman (1995). 'Beyond SES: A Resource Model of Political Participation', American Political Science Review, 89:2, 271-294.

Burns, Nancy, Kay Lehman Schlozman and Sidney Verba (2009). The Private Roots of Public Action, Harvard University Press.

Campbell, Angus (1960). 'Surge and Decline: A Study of Electoral Change', Public Opinion Quarterly 24:3, 397-418.

Campbell, Angus, Philip E. Converse, Warren E. Miller and Donald E. Stokes (1960). The American voter, Chicago: The University of Chicago Press.

Campbell, Rosie and Kristi Winters (2008). 'Understanding Men's and Women's Political Interests: Evidence from a Study of Gendered Political Attitudes', Journal of Elections, Public Opinion and Parties 18:1, 53-74.

Childs, Sarah (2004). 'A British Gender Gap? Gender and Political Participation', The Political Quarterly 75:4, 422-424.

Coffé, Hilde (2013). 'Women Stay Local, Men Go National and Global? Gender Differences in Political Interest', Sex Roles 69:5-6, 323-338.

Coffé, Hilde and Catherine Bolzendahl (2010). 'Same Game, Different Rules? Gender Differences in Political Participation', Sex Roles 62:5-6, 318-333.

Córdova, Abby and Gabriela Rangel (2017). 'Addressing the Gender Gap The Effect of Compulsory Voting on Women's Electoral Engagement', Comparative Political Studies 50:2, 264-290.

Coulson, Tony (1999). 'Voter Turnout in Canada: Findings from the 1997 Canadian Election Study', Electoral Insight - Participation In The Electoral Process, 1:2, 18-22. 
Dassonneville, Ruth and Ian McAllister (2018). 'Gender, Political Knowledge, and Descriptive Representation: The Impact of Long-Term Socialization', American Journal of Political Science 62:2, 249-265.

de Vreese, Claes H., Edmund Lauf and Peter Jochen (2007). 'The media and European Parliament elections: Second-rate coverage of a second-order event?', in Wouter van der Brug and Cees van der Eijk (eds). European Elections \& Domestic Politics: Lessons from the Past and Scenarios for the Future. Notre Dame: University of Notre Dame Press, 116-130.

Dow, Jay K. (2009). 'Gender Differences in Political Knowledge: Distinguishing Characteristics-Based and Returns-Based Differences', Political Behavior 31:1, 117136.

Engeli, Isabelle, Thanh-Huyen Ballmer-Cao, and Marco Giugni (2006). 'Gender Gap and Turnout in the 2003 Federal Elections', Swiss Political Science Review, 12:4, 217-242.

Fairlie, Robert W. (2005). 'An extension of the Blinder-Oaxaca decomposition technique to logit and probit models', Journal of Economic and Social Measurement 30:4, 305-316.

Fortin-Rittberger, Jessica and Berthold Rittberger (2014). 'Do electoral rules matter? Explaining national differences in women's representation in the European Parliament', European Union Politics 15:4, 496-520.

Fraile, Marta (2014). 'Do Women Know Less About Politics Than Men? The Gender Gap in Political Knowledge in Europe', Social Politics: International Studies in Gender, State \& Society 21:2, 261-289.

Franklin, Mark N. (2004). Voter Turnout and the Dynamics of Electoral Competition in Established Democracies since 1945, Cambridge University Press.

Gidengil, Elisabeth, André Blais, Neil Nevitte and Richard Nadeau (2004). Citizens, Vancouver: UBC Press.

Gidengil, Elisabeth, Elisabeth Goodyear-Grant, Neil Nevitte and André Blais (2005). 'Gender, Knowledge, and Social Capital', in Brenda O'Neill and Elisabeth Gidengil (eds). Gender and Social Capital. Routledge, 241-272.

Gosnell, Harold F. (1930). Why Europe votes., Chicago, Ill.: The University of Chicago Press.

Harell, Allison (2009). 'Equal Participation but Separate Paths?: Women's Social Capital and Turnout', Journal of Women, Politics \& Policy 30:1, 1-22.

Hix, Simon (2006). 'Why the EU needs (Left-Right) Politics? Policy Reform and Accountability are Impossible without It', Notre Europe Policy Paper, 19, 1-27.

Inglehart, Margaret L. (1981). 'Political Interest in West European Women: An Historical and Empirical Comparative Analysis', Comparative Political Studies 14:3, 299-326.

Inglehart, Ronald and Pippa Norris (2003). Rising Tide: Gender Equality and Cultural Change Around the World, Cambridge University Press.

Jann, B. (2008). 'The Blinder-Oaxaca decomposition for linear regression models', Stata Journal 8:4, 453-479.

Jones, F. L. (1983). 'On Decomposing the Wage Gap: A Critical Comment on Blinder's Method', Journal of Human Resources 18:1, 126-130. 
Karp, Jeffrey A. and David Brockington (2005). 'Social Desirability and Response Validity: A Comparative Analysis of Overreporting Voter Turnout in Five Countries', Journal of Politics 67:3, 825-840.

Kim, Chang Hwan (2010). 'Decomposing the Change in the Wage Gap Between White and Black Men Over Time, 1980-2005: An Extension of the Blinder-Oaxaca Decomposition Method', Sociological Methods \& Research 38:4, 619-651.

Kittilson, Miki Caul and Leslie Schwindt-Bayer (2010). 'Engaging Citizens: The Role of Power-Sharing Institutions', The Journal of Politics 72:4, 990-1002.

Larcinese, Valentino (2007). 'Does political knowledge increase turnout? Evidence from the 1997 British general election', Public Choice 131:3-4, 387-411.

Mayer, Nonna (2010). Sociologie des comportements politiques, Paris: Armand Colin.

Milner, Henry (2002). Civic Literacy: How Informed Citizens Make Democracy Work, Hanover: Tufts.

Mondak, Jeffery J. and Mary R. Anderson (2004). 'The Knowledge Gap: A Reexamination of Gender-Based Differences in Political Knowledge', The Journal of Politics 66:2, 492512.

Mood, Carina (2010). 'Logistic Regression: Why We Cannot Do What We Think We Can Do, and What We Can Do About It', European Sociological Review 26:1, 67-82.

Morin-Chassé, Alexandre, Damien Bol, Laura B. Stephenson, and Simon Labbé St-Vincent (2017). 'How to Survey About Electoral Turnout? The Efficacy of the Face-Saving Response Items in 19 Different Contexts', Political Science Research and Methods, 5:3, $575-584$.

Norris, Pippa (2002). 'Women's Power at the Ballot Box', in Rafael López Pintor and Maria Gratschew (eds). Voter Turnout from 1945 to 2000: A Global Report on Political Participation. IDEA, 95-104.

Norris, Pippa (2007). 'New Feminist Challenges to the Study of Political Engagement', in Russell J. Dalton and Hans-Dieter Klingemann (eds). The Oxford Handbook of Political Behavior. Oxford University Press, 724-743.

Norris, Pippa and Ronald Inglehart (2005). 'Gendering Social Capital: Bowling in Women's Leagues?', in Brenda O'Neill and Elisabeth Gidengil (eds). Gender and Social Capital. Routledge, 241-272.

Oaxaca, Ronald (1973). 'Male-Female Wage Differentials in Urban Labor Markets', International Economic Review 14:3, 693-709.

Ondercin, Heather L., and Daniel Jones-White (2011). 'Gender Jeopardy: What is the Impact of Gender Differences in Political Knowledge on Political Participation?', Social Science Quarterly, 92:3, 675-694.

Pekkarinen, Tuomas (2012). 'Gender Differences in Education', Nordic Economic Policy Review 1, 165-196.

Prior, Markus (2010). 'You've Either Got It or You Don't? The Stability of Political Interest over the Life Cycle', The Journal of Politics, 72:3, 747-766. 
Reif, Karlheinz and Hermann Schmitt (1980). 'Nine Second-Order National Elections - a Conceptual Framework for the Analysis of European Election Results', European Journal of Political Research 8:1, 3-44.

Schakel, Arjan H., and Charlie Jeffery (2013). 'Are Regional Elections really "Second-Order" Elections?', Regional Studies, 47:3, 323-341.

Schmitt, Hermann; Hobolt, Sara B.; Popa, Sebastian A.; Teperoglou, Eftichia; European Parliament, Directorate-General for Communication, Public Monitoring Unit (2016): European Parliament Election Study 2014, Voter Study, First Post-Election Survey. GESIS Data Archive, Cologne. ZA5160 Data file Version 4.0.0, doi:10.4232/1.12628

Smiley, Marion (1999). 'Democratic Citizenship: A Question of Competence?', in Stephen L. Elkin and Karol Edward Soltan (eds). Citizen Competence and Democratic Institutions. University Park: Penn State Press, 371-383.

Söderlund, Peter, Hanna Wass and André Blais (2011). 'The impact of motivational and contextual factors on turnout in first- and second-order elections', Electoral Studies 30:4, 689-699.

Stadelmann-Steffen, Isabelle, and Daniela Koller (2014). 'What Type of Resources? Household Effects and Female Electoral Participation', Swiss Political Science Review, 20:4, 529-549.

Stephenson, Laura B., André Blais, Damien Bol and Filip Kostelka (2017). Making Electoral Democracy Work. V1, 2017, Harvard Dataverse, available at doi:10.7910/DVN/RR0NNQ.

Stolle, Dietlind and Elisabeth Gidengil (2010). "What Do Women Really Know? A Gendered Analysis of Varieties of Political Knowledge," Perspectives on Politics 8:1, 93-109.

Tingsten, Herbert (1963). Political behavior: studies in election statistics, Bedminster Press.

van Klingeren, M., M. Orozco, J. Spanje and Claes de Vreese (2015). Party Financing and Referendum Campaigns in EU Member States, Brussels: European Parliament.

Verba, Sidney, Nancy Burns and Kay Lehman Schlozman (1997). 'Knowing and Caring about Politics: Gender and Political Engagement', The Journal of Politics 59:4, 1051-1072.

Verba, Sidney, Norman H. Nie and Jae-on Kim (1978). Participation and Political Equality: A Seven-Nation Comparison, University of Chicago Press. 